\title{
The Influence of Students'learning behaviour on The Utilization of School Library as Learning Resources
}

\section{Pengaruh Perilaku Belajar Peserta Didik Terhadap Pemanfaatan Perpustakaan Sekolah Sebagai Sumber Belajar}

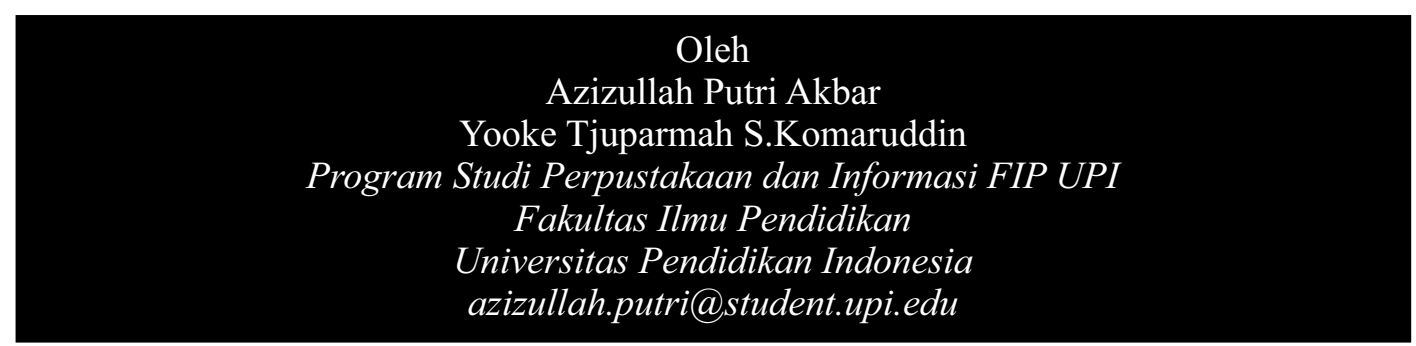

Abstract. This research is motivated by the emergence of the information technology era in which library turns as the place for acquiring information, notably in school. Based on that background, this research is focused on the student's attitude and behavior, and student's learning interest towards school library utilization as a learning resource. The student's behavior was observed across the x-axis and the utilization of library as a learning resource in y-axis. Student's attitude was measured by means of attitude sub-variable which consists of three indicators: cognitive, affective, and conative. Student's behavior was measured by two indicators, namely learning behavior and reading behavior. Furthermore, student's learning interest consists of behave, attention and feeling. This research employs a descriptive design with some quantification to enhance the analysis. Furthermore, the data are collected by using closed questionnaire and Likert Scale. Then the data are analyzed by using correlation analysis and simple linear regression. The results revealed that student's learning behavior has a significant connection and influence (0.841) towards the utilization of school library as a learning resource. Based on this result, it can be recommended that school libraries are expected to develop its materials to increase the level of student's attitude, behavior and interest regarding to utilize library as a learning resource.

Keywords: learning attitude, library materials utilization, learning resources, students.

Abstrak. Masalah yang menjadi kajian dalam penelitian ini difokuskan pada sikap, kebiasaan, dan minat belajar peserta didik terhadap pemanfaatan perpustakaan sekolah sebagai sumber belajar. Penelitian ini terdiri dari perilaku belajar peserta didik (X) dan pemanfaatan perpustakaan sekolah sebagai sumber belajar (Y). Perilaku belajar peserta didik diukur melalui sub variabel sikap yang terdiri dari tiga indikator yaitu kognitif, afektif, dan konatif, dan kebiasaan terdiri dari dua indikator yaitu kebiasaan belajar dan kebiasaan membaca, sedangkan minat belajar terdiri dari perbuatan, perhatian, dan perasaan. Metode penelitian yang digunakan adalah studi deskriptif dengan pendekatan kuantitatif. Teknik pengumpulan data menggunakan kuesioner tertutup dengan menggunakan Skala Likert dan menggunakan analisis data korelasi, serta untuk melihat besar pengaruhnya menggunakan koefisien determinasi dan regresi linier sederhana. Berdasarkan hasil analisis data, diketahui bahwa perilaku belajar peserta didik mempunyai tingkat hubungan dan berpengaruh signifikan terhadap pemanfaatan perpustakaan sekolah sebagai sumber belajar, dengan signifikansi pengaruh sebesar 0,841. Rekomendasi

pada penelitian ini perpustakaan sekolah diharapkan dapat mengembangkan bahan perpustakaan sehingga meningkatkan keberagaman sikap, kebiasaan, dan minat belajar peserta didik untuk memanfaatkan perpustakaan sekolah sebagai sumber belajar.

Kata kunci : Perilaku belajar, Pemanfatan bahan perpustakaan, Sumber belajar dan Peserta didik 
PENDAHULUAN

endidikan memiliki peranan
penting dalam meningkatkan
sumber daya manusia, baik dari segi pengetahuan dan pengalaman, maupun keterampilan. Suatu lembaga pendidikan khususnya sekolah merupakan tempat para guru memberikan informasi dalam kegiatan belajar sehingga diperlukan sumber belajar yang mendukung proses belajar mengajar di sekolah. Sumber belajar yang ada disekolah yaitu perpustakaan. perpustakaan sekolah adalah sarana yang membantu dalam proses belajar mengajar bagi guru dan peserta didik. Untuk memperoleh sumber belajar yang relevan diperlukan perilaku belajar peserta didik yang baik.

Sumber belajar merupakan komponen yang penting dalam proses belajar untuk meningkatkan kualitas pembelajaran di sekolah. Oleh karena itu pemanfaatan perpustakaan sekolah sebagai sumber belajar untuk referensi peserta didik pada kegiatan belajar. Namun pada kenyataannya, Perilaku belajar peserta didik dalam memanfaatkan perpustakaan sebagai sumber belajar masih rendah. Padahal telah tersedia layanan dan fasilitas perpustakaan seperti bahan perpustakaan, ruang baca, internet, dan hal lain yang berkaitan dengan sumber belajar sebagai informasi.

Perilaku belajar peserta didik melipu- ti sikap terdiri dari tiga komponen yaitu kognitif (pengetahuan), afektif (perasaan), dan konatif (tindakan). Sikap peserta didik yang belum efektif karena bahan perpustakaan sekolah belum dapat memenuhi kebutuhan informasinya. Kebiasaan peserta didik terdiri dari kebiasaan belajar dan kebiasaan membaca. Sedangkan minat belajar peserta didik yang masih rendah dalam memanfaatkan perpustakaan sekolah sebagai sumber belajar.

Berdasarkan latar belakang masalah penelitian di atas maka dirumuskan pokok permasalahan, ada rumusan masalah umum dan rumusan masalah khusus. Rumusan masalah umum yaitu: "Bagaimana pengaruh perilaku belajar peserta didik terhadap pemanfaatan perpustakaan sekolah sebagai sumber belajar pada perpustakaan SMP Negeri 5 Bandung". Rumusan masalah khusus,yaitu Seberapa besar pengaruh sikap belajar peserta didik terhadap pemanfaatan perpustakaan sekolah sebagai sumber belajar pada perpustakaan SMP Negeri 5 Bandung, Seberapa besar pengaruh kebiasaan peserta didik terhadap pemanfaatan perpustakaan sekolah sebagai sumber belajar pada perpustakaan SMP Negeri 5 Bandung, dan Seberapa besar pengaruh minat belajar peserta didik terhadap pemanfaatan perpustakaan sekolah sebagai sumber belajar pada perpustakaan SMP Negeri 5 Bandung. 
Penelitian ini bertujuan untuk mengetahui perilaku belajar peserta didik terhadap pemanfaatan perpustakaan sekolah sebagai sumber belajar pada perpustakaan SMP Negeri 5 Bandung. Adapun tujuan khusus penelitian ini yaitu untuk mengetahui sikap belajar peserta didik terhadap pemanfaatan perpustakaan sekolah sebagai sumber belajar pada perpustakaan SMP Negeri 5 Bandung, untuk mengetahui kebiasaan peserta didik terhadap pemanfaatan perpustakaan sekolah sebagai sumber belajar pada perpustakaan SMP Negeri 5 Bandung, dan untuk mengetahui minat belajar peserta didik terhadap pemanfaatan perpustakaan sekolah sebagai sumber belajar pada perpustakaan SMP Negeri 5 Bandung.

Manfaat penelitian ini secara teoritis diharapkan dapat memberikan masukan bagi pengembang ilmu perpustakaan, khususnya mengenai perilaku belajar peserta didik terhadap pemanfaatan perpustakaan sekolah sebagai sumber belajar. Sedangkan manfaat secara praktis terdiri dari peneliti, yaitu memberikan dan meningkatkan pengetahuan dan pengalaman yang menumbuhkan kemampuan dan keterampilan meneliti, bagi perpustakaan sekolah yaitu, sebagai masukan dan bahan pertimbangan dalam meningkatkan periaku belajar peserta didik dalam memanfaatkan perpustakaan sekolah sebagai sumber belajar, bagi pemustaka yaitu, penelitian ini diharapkan bernilai positif yaitu sikap, kebiasaan, dan minat peserta didik meningkat dalam memanfaatkan perpustakaan sekolah sebagai sumber belajar.

Belajar dapat membawa perubahan bagi peserta didik baik perubahan pengetahuan, sikap, maupun keterampilan. Belajar adalah kegiatan yang perlu dilakukan di lingkungan sekolah sehingga peserta didik mengalami perubahan tingkah laku yang disebut dengan perilaku belajar. Setiap perilaku selalu ditandai dengan ciri-ciri perubahan spesifik. Menurut Siregar (2010, hlm. 5) ciri-ciri belajar adalah sebagai berikut.

a. Adanya kemampuan baru atau perubahan. Perubahan tingkah laku tersebut bersifat pengetahuan (kognitif), keterampilan (psikomotorik), maupun nilai dan sikap (afektif).

b. Perubahan itu tidak berlangsung sesaat saja, melainkan menetap atau dapat disimpan.

c. Perubahan itu tidak terjadi begitu saja, melainkan harus dengan usaha. Perubahan terjadi akibat interaksi dengan lingkungan.

Adapun beberapa perwujudan perilaku belajar yang lebih sering tampak adalah perubahan. Menurut Syah (2011, hlm. 116-119) mengenai perwujudan perilaku belajar, yaitu:

a. Sikap

Sikap adalah pandangan atau kecenderungan mental. Menurut Bruno (dalam Syah, 2011, hlm. 118), sikap (attitude) adalah" 
kecenderungan yang relatif menetap untuk bereaksi". Pada prinsipnya sikap menjadi suatu kecenderungan peserta didik untuk bertindak dengan cara tertentu.

b. Kebiasaan Setiap peserta didik yang mengalami proses belajar, maka kebiasaannya akan tampak berubah. Menurut Burghart (dalam Syah, 2011, hlm. 116) “... kebiasaan timbul karena proses penyusutan kecenderungan respon dengan menggunakan stimulasi yang berulang-ulang". Dalam proses belajar, pembiasaan dapat mengurangi perilaku yang tidak diperlukan.

c. Pengamatan

Pengamatan artinya proses menerima dan memberi rangsangan yang masuk melalui indera seperti mata dan telinga". Berkat pengalaman belajar seorang peserta didik akan mampu mencapai pengamatan yang benar objektif sebelum mencapai pengertian. Pengamatan yang salah akan mengakibatkan timbulnya pengertian yang salah pula.

d. Tingkah Laku Afektif

Tingkah laku afektif adalah tingkah $1 \mathrm{aku}$ y ang menyangku t keanekaragaman perasaan seperti takut, marah, sedih, kecewa, dan senang. Tingkah laku seperti ini tidak terlepas dari pengaruh pengalaman belajar.

Setiap individu memiliki perilaku yang berbeda ketika belajar. Perilaku ini dilakukan secara berulang-ulang dan konsisten. Perilaku belajar tidak dirasakan sebagai beban, tetapi sebagai suatu kebutuhan. Untuk memperoleh perilaku belajar yang baik dapat melalui sikap, kebiasaan, dan minat belajar yang dimilki oleh seseorang, sebagai berikut.
1. Sikap

Menurut Nuryanti (2008, hlm. 61) sikap adalah "cara seseorang menerima atau menolak sesuatu yang didasarkan pada cara dia memberi penilaian terhadap obyek tertentu yang berguna ataupun tidak bagi dirinya".

Menurut Azwar Struktur sikap (2000, hlm. 24-27) terdiri atas tiga komponen yang saling menunjang, yaitu:

(1) Komponen Kognitif(cognitive)

Komponen kognitif berisi persepsi, kepercayaan, dan stereotipe yang dimilki individu mengenai sesuatu. Komponen kognitif ini dapat disamakan dengan pandangan terutama menyangkut masalah isu atau problem yang kontroversial.

(2) Komponen Afektif (affective)

Komponen afektif merupakan perasaan individu terhadap objek sikap dan menyangkut masalah emosi.

(3) Komponen Konatif (conative atau perilaku)

Komponen konatif dalam struktur sikap menunjukkan bagaimana perilaku atau kecenderungan berperilaku yang ada dalam diri seseorang berkaitan dengan objek sikap yang dihadapi.

\section{Kebiasaan}

Kebiasaan adalah serangkaian perbuatan seseorang secara berulangulang untuk hal yang sama dan berlangsung tanpa proses berfikir lagi. Kebiasaan terbentuk melalui enam tahapan yang diungkapkan oleh Elfiky (2008, hlm. 88) bahwa, "kebiasaan terbentuk melalui enam tahapan yaitu berfikir, perekaman, pengulangan, penyimpanan, pengulangan, dan kebiasaan". 
a. Kebiasaan belajar

Kebiasaan belajar merupakan serangkaian tingkah laku yang dilakukan secara konsisten atau berulang oleh peserta didik dalam kegiatan belajarnya.

Kebiasaan belajar merupakan perilaku yang sudah tertanam dalam diri individu yang dipertegas oleh Aunurrahman (2009, hlm. 185) berpendapat dalam bukunya "Kebiasaan belajar adalah perilaku yang telah tertanam dalam waktu yang relatif lama sehingga memberikan ciri dalam aktivitas belajar yang dilakukan oleh peserta didik".

b. Kebiasaan membaca

Kebiasaan adalah kegiatan yang dilakukan secara berulang ulang dan konsisten. Begitu pula dengan kebiasaan membaca, membaca adalah usaha untuk mengetahui sesuatu yang tersimpan dalam suatu bahan bacaan. Bagi seseorang untuk mengetahui isi suatu bacaan kunci utamanya adalah membaca. Menurut Bafadal (2009, hlm. 193) ahwa "Membaca merupakan kegiatan kompleks dan disengaja, dalam hal ini berupa proses berfikir yang didalamnya terdiri dari berbagai aksi yang bekerja secara terpadu mengarah kepada suatu tujuan yaitu memahami makna paparan tertulis secara keseluruhan".

\section{Minat}

Minat mengarahkan individu terhadap suatu obyek atas dasar rasa senang dan tidak senang. Perasaan inilah yang merupakan dasar suatu minat. Menurut Slameto (2010, hlm. 180) bahwa minat tidak dibawa sejak lahir melainkan diperoleh melalui hasil belajar.
Menurut Hadis (2006, hlm. 61) menjelaskan bahwa "Proses perubahan perilaku ditunjukan oleh peserta didik menjadi tahu, menjadi terampil, menjadi berbudi, dan menjadi manusia yang mampu menggunakan akal pikirannya sebelum bertindak dan mengambil keputusan untuk melaksanakan sesuatu".

Menurut Riva'i \& Sudjana (dalam Rosalin, 2008, hlm. 4) membagi jenisjenis sumber belajar menjadi beberapa, yaitu sebagai berikut.

a. Sumber belajar tercetak, seperti buku, majalah, brosur, koran, enksiklopedia, kamus, dan booklet.

b. Sumber belajar non cetak, seperti film, slide, video, audio cassete, transparansi, realita, dan objek.

c. Sumber belajar yang berbentuk fasilitas, seperti perpustakaan, ruangan belajar, carrel, studio, dan lapangan olahraga.

d. Sumber belajar berupa kegiatan, seperti wawancara, kerja kelompok, observasi, simulasi, dan permainan.

e. Sumber belajar berupa lingkungan di masyarakat, seperti taman, kebun raya museum, pasar, dan toko.

Perpustakaan sekolah sebagai bagian integral di sekolah karena merupakan komponen utama pada pendidikan di sekolah, diharapkan dapat mendukung pencapaian tujuan sesuai dengan kurikulum. Perpustakaan sekolah dapat bermanfaat apabila benar-benar memperlancar pencapaian tujuan proses belajar mengajar di sekolah.

Koleksi perpustakaan sekolah adalah sejumlah bahan atau sumber-sumber informasi, baik berupa buku ataupun bahan bukan buku yang dikelola untukkepentingan PBM disekolah yang 
bersangkutan. Koleksi perpustakaan dengan mudah dimanfaatkan oleh setiap pengguna perpustakaan. Selain itu perpustakaan juga harus terus berkembang. Seperti yang diungkapkan oleh Sulistyo-Basuki (1993, hlm. 34) bahwa:

Perpustakaan dimulai dengan koleksi terbatas, perpustakaan terus berkembang walaupun tidak selalu sama dengan laju pertumbuhan. Perpustakaan harus berkembang karena pemustaka perpustakaan menghendaki koleksi perpustakaan yang mampu mengikuti kemajuan ilmu pengetahuan.

Menurut Handoko (2003, hlm. 27) pemanfaatan koleksi perpustakaan terdapat dua faktor mempengaruhi antara lain:

a. Faktor internal yang meliputi:

1) Kebutuhan, yang dimaksud adalah kebutuhan akan informasi yang diperlukan.

2) Motif, merupakan sesuatu yang melingkupi semua penggerak, alasan atau dorongan yang menyebabkannya berbuat sesuatu.

3) Minat adalah kecenderungan hati yang tinggi terhadap sesuatu.

b. Faktor eksternal yang meliputi:

1) Kelengkapan koleksi, yaitu banyaknya koleksi yang dimanfaatkan informasinya oleh peserta didik.

2) Keterampilan petugas perpustakaan dalam melayani pengguna, yaitu keterampilan petugas perpustakaan dalam melayani pengguna dapat dilihat melalui kecepatan mereka dalam memberikan layanan.

3) Keterbatasan fasilitas dalam pen- carian kembali adalah sarana akses koleksi perpustakaan.

\section{Metode}

Pada penelitian ini populasi yang diteliti adalah seluruh pemustaka perpustakaan sekolah, yaitu peserta didik kelas VII,VIII, dan IX. Populasi yang digunakan untuk penelitian ini adalah pengunjung perpustakaan bulan maret da april 2014 yang berjumlah 599 orang. Teknik pengambilan sampel yang digunakan adalah Nonprobability Sampling dengan teknik sampling insidental. Untuk menentukan jumlah sampel yang diperlukan sebagai data digunakan rumus Yamane (Bungin, 2005, hlm. 105) penentuan sampel mengambil presisi ditetapkan 10\% dengan tingkat kepercayaan 90\% sehingga diperoleh sampel sebanyak 86 peserta didik. Metode yang digunakan metode deskriptif dengan pendekatan kuantitatif.

\section{HASIL DAN PEMBAHASAN}

Berdasarkan hasil penyebaran kuesioner dan penelitian yang telah dilakukan, maka diperoleh data sebagai berikut. Analisis korelasi untuk mengetahui pengaruh variabel $\mathrm{X}$ (Perilaku Belajar Peserta didik) terhadap variabel Y (pemanfaatan perpustakaan sekolah sebagai sumber belajar) bahwa korelasi antara perilaku belajar peserta didik dengan pemanfaatan perpustakaan sekolah sebagai sumber 
perpustakaan SMP Negeri 5 Bandung sebesar 0,841, jika nilai r diinterpretasikan dengan menggunakan interval koefisien korelasi, maka nilai r berada pada interval koefisien korelasi $\pm 0,80- \pm 1,000$. Dengan demikian besarnya korelasi $\mathrm{r}=0,841$ dapat dikategorikan sangat kuat. Untuk mengetahui apakah nilai $r$ tersebut memiliki arti atau tidak, maka dilakukan uji-t sebesar 14,245.

Dari perhitungan nilai $\mathrm{r}$ dan $\mathrm{t}$ diatas maka dapat disimpulkan uji korelasinya sebagai berikut.

Tabel

Kesimpulan Uji Korelasi

\begin{tabular}{|c|c|c|c|c|}
\hline $\mathbf{R}$ & Kriteria & thitung & ttabel & Keterangan \\
\hline 0,841 & $\begin{array}{c}\text { Sangat } \\
\text { Kuat }\end{array}$ & 14,245 & 1,980 & Signifikan \\
\hline
\end{tabular}

Berdasarkan ketentuan, jika r hitung lebih kecil dan $\mathrm{r}$ tabel, maka Ho diterima, dan $\mathrm{H}_{1}$ ditolak. Tetapi jika $r$ hitung lebih besar dari $r$ tabel maka Ho ditolak, dan $\mathrm{H}_{1}$ diterima. Dilihat dari tabel diatas tampak bahwa $r$ hitung lebih besar dari $r$ tabel maka $\mathrm{H}_{1}$ diterima, dengan demikian korelasi 0,841 itu signifikan dan $\mathrm{H}_{1}$ diterima. Maka hipotesisnya yaitu "Terdapat pengaruh yang signifikan antara perilaku belajar peserta didik terhadap pemanfaatan perpustakaan sekolah sebagai sumber belajar pada perpustakaan SMP Negeri 5 Bandung".

Jika dari hasil pengujian koefisisen korelasi menghasilkan korelasi yang signifikan, maka besarnya pengaruh antara variabel independen variabel dependen dapat dicari dengan koefisien determinasi. Koefisien determinasi digunakan untuk mengukur besarnya pengaruh variabel perilaku belajar peserta didik terhadap pemanfaatan perpustakaan sekolah sebagai sumber belajar pada perpustakaan SMP Negeri 5 Bandung. Perhitungan koefisien determinasi mengunakan rumus sebagai berikut.

$$
\begin{gathered}
D=\left(\mathrm{r}_{\mathrm{xy}}\right)^{2} \times 100 \%=(0,841)^{2} \times 100 \% \\
=70,73
\end{gathered}
$$

Berdasarkan hasil dari koefisien determinasi, maka dapat diketahui nilai koefisien determinasi sebesar 70,73. Hal ini menunjukkan bahwa pengaruh variabel X perilaku belajar peserta didik terhadap variabel $\mathrm{Y}$ pemanfaatan perpustakaan sekolah sebagai sumber belajar sebesar 70,73\% sedangkan sisanya sebesar 29,27\% dipengaruhi oleh faktor lain di luar variabel yang diteliti.

Selain itu, peneliti juga melakukan uji korelasi pada setiap sub variabel dari variabel $\mathrm{X}$ terhadap variabel $\mathrm{Y}$. Tujuan dilakukannya uji korelasi pada setiap sub variabel yaitu untuk mendapatkan hasil data yang akurat dan mengetahui sub variabel mana yang paling berpengaruh terhadap variabel Y.

Adapun hasil perhitungan korelasi dari setiap sub variabel adalah sebagai berikut. a. Perhitungan uji koefisien korelasi dari sub variabel $\mathrm{X}_{1}$ (sikap belajar peserta didik) terhadap variabel Y (pemanfaatan perpustakaan sekolah 
sebagai sumber belajar) di perpustakaan

SMP Negeri 5 Bandung digunakan dengan bantuan IBM SPSS Statistics Version 22, sebagai berikut.

Berdasarkan hasil penelitian diketahui bahwa hasil korelasi dari sikap belajar peserta didik terhadap pemanfaatan perpustakaan sekolah sebagai sumber belajar di perpustakaan SMP Negeri 5 Bandung sebesar 0,649. Jika nilai $r$ tersebut diinterpretasikan dengan menggunakan kriteria-kriteria interval korelasi, maka nilai $\mathrm{r}$ berada pada interval koefisien korelasi $\pm 0,60- \pm 0,779$. Dengan demikian, besarnya korelasi $\mathrm{r}=0,649$ dapat dikategorikan kuat.

Untuk mengetahui besarnya pengaruh variabel independen terhadap variabel dependen dapat dicari dengan koefisien determinasi. Dengan kata lainnilai koefisien determinasi digunakan untuk mengukur besarnya pengaruh sikap belajar peserta didik terhadap pemanfaatan perpustakaan sekolah sebagai sumber belajar di perpustakaan SMP Negeri 5 Bandung.

Perhitungan koefisien determinasi menggunakan rumus sebagai berikut.

$$
\begin{gathered}
D=\left(\mathrm{r}_{\mathrm{xy}}\right)^{2} \times 100 \%=(0,649)^{2} \times 100 \%= \\
42,12
\end{gathered}
$$

Berdasarkan hasil dari koefisien determinasi tersebut, dapat diketahui bahwa nilai koefisien determinasi sebesar 42,12. Hal ini menunjukkan bahwa pengaruh sikap belajar peserta terhadap pemanfaatan perpustakaan sekolah sebagai sumber belajar di perpustakaan SMP Negeri 5 Bandung sebesar $42,12 \%$, sedangkan sisanya sebesar $57,88 \%$ dipengaruhi oleh faktor lain yang tidak diteliti oleh peneliti.

b. Perhitungan uji koefisien korelasi dari sub variabel $\mathrm{X}_{2}$ (kebiasaan belajar peserta didik) terhadap variabel $\mathrm{Y}$ (pemanfaatan perpustakaan sekolah sebagai sumber belajar) di perpustakaan SMP Negeri 5 Bandung digunakan dengan bantuan IBM SPSS Statistics Version 22, sebagai berikut.

Berdasarkan hasil penelitian diketahui bahwa hasil korelasi dari kebiasaan belajar peserta didik terhadap pemanfaatan perpustakaan sekolah sebagai sumber belajar di perpustakaan SMP Negeri 5 Bandung sebesar 0,717. Jika nilai $r$ tersebut diinterpretasikan dengan menggunakan kriteria-kriteria interval korelasi, maka nilai $r$ berada pada interval koefisien korelasi $\pm 0,60$ - $\pm 0,779$. Dengan demikian, besarnya korelasi $\mathrm{r}=0,717$ dapat dikategorikan kuat.

Untuk mengetahui besarnya pengaruh variabel independen terhadap variabel dependen dapat dicari dengan koefisien determinasi. Dengan kata lain nilai koefisien determinasi digunakan untuk mengukur besarnya pengaruh kebiasaan belajar peserta didik terhadap pemanfaatan perpustakaan 
sebagai sumber belajar di perpustakaan SMP Negeri 5 Bandung. Perhitungan koefisien determinasi menggunakan rumus sebagai berikut.

$$
\begin{gathered}
D=\left(\mathrm{r}_{\mathrm{xy}}\right)^{2} \times 100 \%=(0,717)^{2} \times 100 \%= \\
51,40
\end{gathered}
$$

Berdasarkan hasil dari koefisien determinasi tersebut, dapat diketahui bahwa nilai koefisien determinasi sebesar 51,40. Hal ini menunjukkan bahwa pengaruh kebiasaan belajar peserta didik terhadap pemanfaatan perpustakaan sekolah sebagai sumber belajar di perpustakaan SMP Negeri 5 Bandung sebesar $51,40 \%$, sedangkan sisanya sebesar 48,6\% dipengaruhi oleh faktor lain yang tidak diteliti oleh peneliti.

c. Perhitungan uji koefisien korelasi dari sub variabel $\mathrm{X}_{3}$ (minat belajar peserta didik) terhadap variabel Y (pemanfaatan perpustakaan sekolah sebagai sumber belajar) di perpustakaan SMP Negeri 5 Bandung digunakan dengan bantuan IBM SPSS Statistics Version 22, sebagai berikut.

Berdasarkan hasil penelitian diketahui bahwa hasil korelasi dari minat belajar peserta didik terhadap pemanfaatan perpustakaan sekolah sebagai sumber belajar di perpustakaan SMP Negeri 5 Bandung sebesar 0,812. Jika nilai $r$ tersebut diinterpretasikan dengan menggunakan kriteria-kriteria interval korelasi, maka nilai r berada pada interval koefisien korelasi $\pm 0,80- \pm$ 1,000. Dengan demikian, besarnya korelasi $\mathrm{r}=0,812$ dapat dikategorikan sangat kuat.

Untuk mengetahui besarnya pengaruh variabel independen terhadap variabel dependen dapat dicari dengan koefisien determinasi. Dengan kata lain nilai koefisien determinasi digunakan untuk mengukur besarnya pengaruh minat belajar peserta didik terhadap pemanfaatan perpustakaan sekolah sebagai sumber belajar di perpustakaan SMP Negeri 5 Bandung. Perhitungan koefisien determinasi menggunakan rumus sebagai berikut.

$$
D=\left(\mathrm{r}_{\mathrm{xy}}\right)^{2} \times 100 \%=(0,812)^{2} \times 100 \%=
$$

$$
65,93
$$

Berdasarkan hasil dari koefisien determinasi tersebut, dapat diketahui bahwa nilai koefisien determinasi sebesar 65,93 . Hal ini menunjukkan bahwa pengaruh minat belajar peserta didik terhadap pemanfaatan perpustakaan sekolah sebagai sumber belajar di perpustakaan SMP Negeri 5 Bandung sebesar $65,93 \%$, sedangkan sisanya sebesar $34.07 \%$ dipengaruhi oleh faktor lain yang tidak diteliti oleh peneliti.

Dapat disimpulkan bahwa dari setiap sub variabel, diketahui hasil korelasi sub variabel $\mathrm{X}_{1}$ (Sikap Belajar Peserta didik) terhadap variabel $\mathrm{Y}$ (pemanfaatan perpustakaan sekolah sebagai sumber belajar) sebesar 0,649 dengan kategori kuat. Pada sub variabel $\mathrm{X}_{2}$ (Kebiasaan 
Belajar Peserta didik) terhadap variabel Y (pemanfaatan perpustakaan sekolah sebagai sumber belajar) sebesar 0,717 dengan kategori kuat. Sedangkan sub variabel $\mathrm{X}_{3}$ (Minat Belajar Peserta didik) terhadap variabel Y (pemanfaatan perpustakaan sekolah sebagai sumber belajar) sebesar 0,812 dengan kategori sangat kuat.

Dengan demikian sub variabel yang mempunyai pengaruh sangat kuat terhadap pemanfaatan perpustakaan sekolah sebagai sumber belajar di perpustakaan SMP Negeri 5 Bandung yaitu minat belajar peserta didik dengan korelasi sebesar 0,812 .

Uji regresi linier sederhana dilakukan untuk memprediksi seberapa tinggi tingkat korelasi antara variabel independen (perilaku belajar peserta didik) dengan variabel dependen (pemanfaatan perpustakaan sekolah sebagai sumber belajar). Perhitungan tingkat korelasi menggunakan bantuan IBM SPSS Statistics Version 22, sebagai berikut.

Adapun untuk menemukan persamaan regresi, maka diperoleh nilai alpha dan beta. Nilai konstanta adalah 3,781 dan nilai beta $(\beta)$ adalah 0,909 . Regresi linier sederhananya adalah $\mathrm{Y}=$ $3,781+0,909 X$. Hal ini berarti jika perilaku belajar peserta didik sama dengan nol maka pemanfaatan perpustakaan sekolah sebagai sumber belajar adalah 3,781 dan jika perilaku belajar peserta didik dinaikkan sebesar satu satuan maka nilai tingkat pemanfaatan perpustakaan sekolah sebagai sumber belajar meningkat 0,909 .

\section{Pengaruh Perilaku Belajar Peserta Didik terhadap Pemanfatan Perpustakaan Sekolah sebagai Sumber Belajar}

Untuk mengetahui perilaku belajar peserta didik terhadap pemanfaatan perpustakaan sekolah sebagai sumber belajar di perpustakaan SMP Negeri 5 Bandung 0,841 dikategorikan sangat kuat. Hasil penelitian ini sejalan dengan pendapat Darmono (2007, hlm. 10) yang mengungkapkan "Perilaku balajar di lingkungan sekolah dalam kegiatan belajar perlu didukung oleh sarana yang memadai salah satunya adalah perpustakaan sekolah yang berfungsi sebagai sumber belajar".

Selain itu, perilaku belajar juga dipengaruhi dengan ciri-cirinya, seperti yang diungkapkan oleh Surya (dalam Syah, 2011, hlm. 114) bahwa:

a. Perubahan intensional adalah perubahan karena pengalaman atau kegiatan yang dilakukan secara sengaja dan bukan secara kebetulan.

b. Perubahan positif dan aktif adalah perubahan baik dan bermanfaat bagi kehidupan serta sesuai dengan harapan untuk memperoleh sesuatu yang baru, perubahan karena adanya usaha dari 
peserta didik yang bersangkutan.

c. Perubahan efektif adalah perubahan yang membawa pengaruh dan manfaat tertentu bagi peserta didik.

Berdasarkan pendapat di atas dapat diketahui bahwa perilaku belajar merupakan hal yang sangat penting bagi perpustakaan. Perilaku peserta didik dalam mencari informasi sangat menentukan agar informasi yang diperlukan sesuai dengan tujuan dan tidak salah. Perilaku belajar pula yang membantu peserta didik dalam memanfaatkan perpustakaan sebagai sumber belajar untuk menunjang kegiatan pembelajaran. Perilaku belajar yang sesuai akan membawa perubahan dalam proses belajar yang dilakukan oleh peserta didik secara disadari atau tidak disadari. Selain itu perpustakaan perlu mengembangkan dan menghimpun koleksi perpustakaan. Seperti yang diungkapkan oleh Sulistyo Basuki (1993, hlm. 34) bahwa Perpustakaan dimulai dengan koleksi terbatas, perpustakaan terus berkembang walaupun tidak selalu sama dengan laju pertumbuhan. Perpustakaan harus berkembang karena pemustaka perpustakaan menghendaki koleksi perpustakaan yang mampu mengikuti kemajuan ilmu pengetahuan.

Dalam hal ini, perpustakaan sangat perlu melakukan pengembangan terhadap koleksi perpustakaan. Tujuannya untuk membangun dan meningkatkan perilaku belajar peserta didik dalam memanfaatkan perpustakaan sebagai sumber belajar. Perpustakaan sekolah berperan penting di lingkungan sekolah sebagai pusat sumber informasi dalam proses kegiatan belajar bertujuan membantu pemustaka dalam memperoleh informasi.

\section{Pengaruh Sikap Peserta Didik t e r h a d a p e m a $\mathrm{n}$ f a t a Perpustakaan Sekolah sebagai Sumber Belajar}

Untuk mengetahui pengaruh sikap belajar peserta didik terhadap pemanfaatan perpustakaan sekolah sebagai sumber belajar di perpustakaan SMP Negeri 5 Bandung sebesar 0,649. Besaran pengaruh tersebut berada pada kategori kuat.

Hal tersebut sejalan dengan pendapat Nuryanti (2008, hlm. 61) yang menyatakan "sikap merupakan cara seseorang menerima atau menolak sesuatu berdasarkan pada cara dia memberi penilaian terhadap obyek tertentu yang berguna atau tidaknya bagi dirinya”. Sedangkan menurut Kartono (1991, hlm. 309) suatu kecenderungan memberi respon baik positif maupun negatif terhadap orang-orang, benda, ataupun situasi tertentu".

Sikap dianggap suatu kecenderungan peserta didik untuk bertindak dengan cara tertentu. Menurut Azwar (2000, hlm 2427) struktur sikap belajar adalah sebagai 
berikut:

\section{Komponen Kognitif (cognitive)}

Komponen kognitif berisi persepsi, kepercayaan, dan stereotipe yang dimilki individu mengenai sesuatu. Komponen kognitif ini dapat disamakan dengan pandangan terutama menyangkut masalah isu atau problem yang kontroversial.

2. KomponenAfektif(affective)

Komponen afektif merupakan perasaan individu terhadap objek sikap dan menyangkut masalah emosi.

\section{Komponen Konatif(conative)}

Komponen konatif dalam struktur sikap menunjukkan bagaimana perilaku atau kecenderungan berperilaku yang ada dalam diri seseorang berkaitan dengan objek sikap yang dihadapi.

Sikap belajar dilihat dari kegiatan yang dilakukan oleh peserta didik adalah berkunjung ke perpustakaan untuk memanfaatkan koleksi perpustakaan dan untuk membaca. Koleksi bahan perpustakaan merupakan faktor penting penunjang peserta didik berkunjung dan memanfaatkan perpustakaan. Koleksi perpustakaan berkaitan dengan kegiatan belajar mengajar, sehingga koleksinya menarik peserta didik.

Kelengkapan koleksi mempengaruhi sikap peserta didik untuk berkunjung ke perpustakaan untuk belajar maupun membaca. Perpustakaan sekolah menyediakan buku penunjang untuk proses belajar di perpustakaan, peserta didik yang tidak memiliki buku pelajaran dapat meminjam di perpustakaan. Buku penunjang tersebut digunakan sebagai bahan referensi dalam belajar, selain menyediakan buku pelajaran perpustakaan menyediakan koleksi nonfiksi yang digunakan dalam melengkapi dan mengerjakan tugas yang diberikan guru.

Usaha yang dilakukan peserta didik dalam melengkapi sumber belajar berbeda-beda. Usaha tersebut dilakukan untuk menambah bahan penunjang belajar di sekolah. Peserta didik melakukan peminjaman mulai dari berkunjung ke perpustakaan dan meminjam buku di perpustakaan sekolah. Sikap ini membantu peserta didik untuk mencari sumber referensi dengan memanfaatkan perpustakaan.

Berdasarkan pendapat diatas dapat disimpulkan bahwa sikap belajar ditentukan oleh tiga komponen diatas yaitu kognitif, afektif, dan konatif. Sikap belajar pemustaka yang positif maupun negatif ditentukan pula dengan perilaku belajar peserta didik terhadap pemanfaatan perpustakaan sebagai sumber belajar. Sumber belajar yang dimanfaatkan berupa buku, bahan bukan buku, dan bahan perpustakaan lainnya. Selain itu, pemustaka secara langsung memanfaatkan layanan perpustakaan yang ada untuk memenuhi kebutuhan 
informasinya. Sikap siswa dalam memanfaatkan perpustakaan sekolah sebagai sumber belajar bernilai positif dan baik.

\section{Pengaruh Kebiasaan Peserta Didik} t e r h a d p P e m a f a t a n Perpustakaan Sekolah sebagai Sumber Belajar

Untuk mengetahui pengaruh kebiasaan peserta didik terhadap pemanfaatan perpustakaan sekolah sebagai sumber belajar di perpustakaan SMP Negeri 5 Bandung sebesar 0,717 berpengaruh kuat.

Peserta didik yang aktif memanfaatkan perpustakan memiliki pengetahuan yang luas dibandingkan dengan peserta didik yang tidak memanfaatkan perpustakaan. Perpustakaan dijadikan sebagai sumber belajar bagi peserta didik dan bahan rekreasi pada saat istirahat. Rata-rata peserta didik saat istirahat memanfaatkan perpustakaan, mereka menunggu bel masuk dengan membaca novel, majalah, dan bahan perpustakaan lainnya yang berisi hiburan. Hal itu bemula dari dalam diri perserta didik itu sendiri, lama kelamaan kegiatan yang sering dilakukan akan menjadi kebiasaan dan kebiasaan itu pun berlangsung secara berulang-ulang.

Perilaku belajar tersebut sejalan dengan yang diungkapkan oleh Elfiky (2008, hlm. 88) mengemukakan bahwa " kebiasaan terbentuk melalui enam tahapan yaitu berfikir, perekaman, pengulangan, penyimpanan, pengulangan, dan kebiasaan".

Berdasarkan pendapat diatas, untuk melatih kebiasaan diperlukan waktu yang cukup panjang dan didukung dengan enam proses terbentuknya kebiasaan, yaitu berfikir, perekaman, pengulangan, penyimpanan, pengulangan, dan kebiasaan. Jika dikaitkan dengan perpustakaan kebiasaan akan timbul pada diri pemustaka kalau dilakukan secara berulang-ulang serta lama kelaman menjadi kebiasaan. Kebiasaan yang diperoleh tidak hanya kebiasaan belajar tapi akan muncul kebiasaan membaca pemustaka terhadap koleksi perpustakaan yang ada sebagai sumber informasi yang ada di lingkungan sekolah.

Untuk menghadapi ulangan harian peserta didik memanfaatkan perpustakaan untuk melengkapi materi pelajaran, sehingga membuat peserta didik berkunjung ke perpustakaan untuk memperoleh sumber belajar dan informasi yang diperlukan. Hal ini yang dikatakan kebiasaan belajar sejalan dengan keinginan peserta didik.

Kebiasaan belajar adalah perilaku yang sudah tertanam dalam diri individu yang dipertegas oleh Aunurrahman (2009, hlm. 185) bahwa "kebiasaan belajar merupakan perilaku belajar yang tertanam dalam diri individu dalam waktu relatif lama sehingga memberikan ciri dalam aktivitas belajar setiap peserta didik". 
Sedangkan, kebiasaan membaca menurut Bafadal (2005, hlm 153) mengungkapkan bahwa "kebiasaan membaca yaitu kegiatan yang kompleks dan sengaja dilakukan dengan tujuan untuk memahami makna paparan secara tertulis".

Berdasarkan pendapat diatas bahwa kebiasaan belajar dan kebiasaan membaca adalah perilaku penting untuk meningkatkan pemanfaatan perpustakaan sebagai sumber belajar disekolah, karena melalui kebiasaan peserta didik menjadi terbiasa memanfaatkan waktu luangnya untuk berkunjung ke perpustakaan. artinya kebiasaan belajar mempunyai pengaruh yang kuat bagi peserta didik dalam memperoleh sumber belajar yang mendukung kegiatan belajar di sekolah.

\section{Pengaruh Minat Peserta Didik} terh a d a p e m a n f a t a $n$ Perpustakaan Sekolah sebagai Sumber Belajar

Untuk mengetahui pengaruh minat belajar peserta didik terhadap pemanfaatan perpustakaan sekolah sebagai sumber belajar di perpustakaan SMP Negeri 5 Bandung sebesar 0,812 berpengaruh sangat kuat.

Berdasarkan hasil tersebut, minat belajar sangat berpengaruh terhadap pemanfaatan perpustakaan sekolah sebagai sumber belajar di perpustakaan SMP Negeri 5 Bandung. Slameto (2003, hlm. 57) berpendapat bahwa:
"Minat adalah kecenderungan yang tetap untuk memperhatikan dan mengenang beberapa kegiatan. Kegiatan yang diminati seseorang diperhatikan terusmenerus disertai dengan rasa senang. Dengan demikian minat berbeda dengan perhatian, perhatian bersifat sementara (tidak dalam waktu lama), sedangkan minat selalu diikuti perasaan senang sehingga diperoleh kepuasaan."

Koleksi perpustakaan merupakan salah satu faktor pendorong peserta didik untuk berkunjung dan memanfaatkan perpustakaan. Koleksi perpustakaan berkaitan dalam proses belajar sehingga koleksinya dapat menarik peserta didik dan sesuai dengan kurikulum yang berlaku. Jenis koleksi perpustakaan yang diminati pemustaka yaitu bahan perpustakaan fiksi yang bersifat menghibur dan rekreas i.

Minat belajar peserta didik timbul jika ada motivasi dalam diri peserta didik. Motivasi memiliki peranan penting dalam proses belajar mengajar disekolah, peserta didik yang memiliki motivasi untuk belajar akan berusaha mempelajari sesuatu dengan baik dan tekun, berusaha memperoleh hasil yang baik.

Perpustakaan berperan sebagai pusat sumber belajar di sekolah dalam menunjang proses belajar mengajar. Oleh karena itu perpustakan harus menyediakan sarana dan prasarana yang lengkap untuk memenuhi kebutuhan peserta didik. Sarana yang lengkap 
memudahkan peserta didik untuk memanfaatkan perpustakaan sekolah.

Suasana perpustakaan yang tenang memberikan pengaruh yang besar kepada peserta didik dalam pemanfaatan perpustakaan secara maksimal, sehingga membantu konsentrasi belajar peserta didik di perpustakaan. Perpustakaan memberikan pelayanan yang baik,salah satu pelayanan yang terlihat dalam perpustakaan adalah pelayanan sirkulasi. Proses peminjaman perpustakaan merupakan rangkaian kegiatan yang dilakukan untuk peminjaman bahan perpustakaan. Untuk melakukan proses peminjaman peserta didik wajib memiliki kartu anggota perpustakaan. Keberhasilan layanan sirkulasi tergantung pada beberapa faktor antara lain yaitu prosedur peminjaman bahan pustaka yang mudah dimengerti dan cepat dilaksanakan, sehingga prosedur itu dapat dipahami oleh peserta didik. Seluruh peserta didik memahami prosedur peminjaman dan pengembalian buku di perpustakaan.

Berdasarkan pendapat tersebut dapat disimpulkan bahwa perpustakaan menyediakan koleksi perpustakaan yang lengkap, dan relevan untuk memenuhi kebutuhan informasi pemustaka. Koleksi perpustakaan sangat mempengaruhi minat belajar peserta didik untuk berkunjung dan belajar diperpustakaan. Oleh karena itu, perpustakaan sekolah dibentuk menarik sehingga peserta didik memanfaatkan perpustakaan sebagai sumber belajar dalam mendukung kegiatan belajar di sekolah.

\section{SIMPULAN}

Berdasarkan hasil penelitian yang telah dilakukan maka peneliti mengambil kesimpulan bahwa perilaku belajar yang mencakup sikap, kebiasaan, dan minat mempunyai pengaruh yang kuat terhadap pemanfaatan perpustakaan sekolah sebagai sumber belajar. Pengaruh dapat dilihat dari minat belajar peserta didik di perpustakaan SMP Negeri 5 Bandung menunjukkan hasil bahwa semakin baik perilaku belajar peserta didik di perpustakaan akan semakin tinggi pula pemanfaatan perpustakaan sekolah sebagai sumber belajar.

Adapun simpulan dari hasil pengujian terhadap setiap sub variabel $X$ terhadap variabel Y yaitu sebagai berikut.

a. Perilaku belajar pada sikap belajar peserta didik mempunyai pengaruh yang kuat terhadap pemanfaatan perpustakaan sekolah sebagai sumber belajar di perpustakaan SMP Negeri 5 Bandung. Hal ini menunjukkan bahwa sikap belajar peserta didik dalam pemanfaatan perpustakaan baik dan efektif. Semakin baik sikap belajar peserta didik maka semakin meningkat sikap peserta didik untuk memanfaatkan perpustakaan sekolah sebagai sumber belajar.

b. Perilaku belajar pada kebiasaan peserta didik mempunyai pengaruh yang kuat 
terhadap pemanfaatan perpustakaan sekolah sebagai sumber belajar di perpustakaan SMP Negeri 5 Bandung. Hal ini menunjukkan bahwa kebiasaan belajar dan membaca peserta didik terhadap pemanfaatan perpustakaan sekolah sebagai sumber belajar baik dan efektif sehingga membantu peserta didik dalam kegiatan proses belajar di sekolah.

c. Perilaku belajar pada minat belajar peserta didik mempunyai pengaruh yang sangat kuat terhadap pemanfaatan perpustakaan sekolah sebagai sumber belajar di perpustakaan SMP Negeri 5 Bandung. Hal ini menunjukkan bahwa minat belajar peserta didik dalam pemanfaatan perpustakaan baik dan tinggi. Semakin tinggi minat peserta didik untuk berkunjung dan memanfaatkan perpustakaan sekolah sebagai sumber belajar maka semakin meningkat keinginan peserta didik untuk memanfaatkan perpustakaan.

Dengan melihat hasil penelitian dapat disimpulkan bahwa terdapat pengaruh yang positif dan signifikan antara perilaku belajar peserta didik terhadap pemanfaatan perpustakaan sekolah sebagai sumber belajar di SMP Negeri 5 Bandung.

\section{DAFTAR PUSTAKA}

Aunurrahman. (2009). Belajar dan Pembelajaran. Bandung: Alfabeta

Azwar, S. (2000). Sikap Manusia: Teori dan Pengukurannya. Yogyakarta: Pustaka Pelajar Offset.

Bafadal, I. (2009). Pengelolaan Perpustakaan Sekolah. Jakarta : Bumi Aksara.

Bungin, B. (2005). Metodologi Penelitian Kuantitatif. Jakarta: Kencana

Elfiky, I. (2008). Terapi Berfikir Positif. Jakarta: Penerbit Zaman

Hadis, A. (2006). Psikologi dalam Pendidikan. Bandung: Alfabeta

Handoko, M. (2003). Motivasi Daya Pengerak Tingkah Laku. Yogyakarta. Kanisius.

Nuryanti, L. (2008). Psikologi Anak. Jakarta: Indeks.

Slameto.(2010). Belajar dan faktor-faktor yang mempengaruhi. Jakarta: PT Rineka Cipta. 